\title{
Prevalensi dan Pola Sensitivitas Antibiotik Klebsiella pneumoniae dan Escherichia coli Penghasil Extended Spectrum Beta Laktamase di RSUP Dr. M. Djamil Padang
}

\author{
Suci Alillah Muztika ${ }^{1}$, Ellyza Nasrul ${ }^{2}$, Eugeny Alia $^{2}$
}

\begin{abstract}
Abstrak
Prevalensi Escherichia coli dan Klebsiella pneumoniae penghasil Extended spectrum beta Lactamase (ESBL) meningkat dalam beberapa tahun ini. Infeksi bakteri penghasil ESBL memiliki pilihan terapi yang terbatas. Tujuan: Mengetahui prevalensi dan pola sensitivitas antibiotik dari Klebsiella pneumoniae dan Escherichia coli penghasil ESBL di RSUP Dr M Djamil Padang. Metode: Penelitian ini merupakan studi deskriptif dengan rancangan potong lintang terhadap 828 sampel mikrobiologi dengan hasil kultur positif terhadap bakteri Gram negatif pada bulan Juni 2018- Mei 2019 yang memenuhi kriteria inklusi. Identifikasi bakteri, pemeriksaan ESBL dan uji sensitivitas dilakukan dengan alat mikrobiologi otomatis dengan metode kolorimetri dan turbidimetri. Hasil: Prevalensi Klebsiella pneumoniae dan Escherichia coli penghasil ESBL di RSUP Dr M Djamill Padang masing-masing sebanyak 70,9\% dan 75,7\%. Sensitivitas Klebsiella pneumoniae dan Escherichia coli penghasil ESBL adalah 96,4\% dan 98,8 terhadap antibiotik meropenem, 98,9\% dan 99,4\% terhadap antibiotik amikasin, 53,5\% dan 44,8\% terhadap antibiotik sefepim, 46,2\% dan 53,4\% terhadap antibiotik gentamisin serta 31,5\% dan 15,9\% terhadap antibiotik siprofloksasin. Prevalensi Klebsiella pneumoniae dan Escherichia coli penghasil ESBL di RSUP Dr. M Djamil Padang cukup tinggi dengan rata-rata prevalensi kedua bakteri $73,2 \%$. Simpulan: Klebsiella pneumoniae dan Escherichia coli penghasil ESBL sensitif terhadap antibiotik meropenem dan amikasin.
\end{abstract}

Kata kunci: ESBL, Escherichia coli, Klebsiella pneumoniae, prevalensi

\begin{abstract}
Prevalence of Extended-spectrum beta-lactamase-producing Escherichia coli and Klebsiella pneumoniae increase in recent years. Extended-spectrum beta-lactamase (ESBL) producing bacterial infection has a limited therapy option. Objectives: To measured the prevalence and antibiotic susceptibility pattern of Klebsiella pneumoniae and Escherichia coli producing ESBL in Dr. M. Djamil Hospital Padang. Methods: This study was a descriptive cross-sectional study on 828 microbiology sample with positive culture results to Gram-negative bacteria in June 2018 until Mei 2019, which met inclusion criteria. Bacterial identification, ESBL test and antimicrobial susceptibility testing were conducted with automatic microbiology analyzer with colorimetry and turbidimetry methods. Results: Klebsiella pneumoniae and Escherichia coli producing ESBL prevalence in Dr. M Djamil Hospital Padang were $70,9 \%$ and $75,7 \%$, respectively. Klebsiella pneumoniae and Escherichia coli producing ESBL susceptibility toward meropenem were $96,4 \%$ and $98,8 \%$, amikacin $98,9 \%$ and $99,4 \%$, cefepime $53,5 \%$ and $44,8 \%$, gentamicin $46,2 \%$ and $53,4 \%$, and ciprofloxacin $31,5 \%$ and $15,9 \%$ respectively.Klebsiella pneumoniae and Escherichia coli producing ESBL prevalence in Dr. M Djamil Hospital Padang were relatively high, with the average prevalence of both bacteria $73,2 \%$. Conclusions: Klebsiella pneumoniae and Escherichia coli producing ESBL are susceptible to meropenem and amikacin.
\end{abstract}

Keywords: ESBL, Escherichia coli, Klebsiella pneumoniae, prevalence 
Affiliasi penulis: ${ }^{1}$ Program Pendidikan Dokter Spesialis Patologi Klinik, Fakultas Kedokteran, Universitas Andalas, Padang, Indonesia. ${ }^{2}$ Bagian Patologi Klinik, Fakultas Kedokteran, Universitas Andalas, Padang, Indonesia.

Korespondensi: Suci Alillah Muztika, Email: sucialillah@gmail.com Telp: 081365520846

\section{PENDAHULUAN}

Resistensi terhadap antibiotik merupakan masalah kesehatan global yang mengancam pengobatan penyakit infeksi serta menyebabkan disabilitas dan kematian. ${ }^{1}$ Perkembangan resistensi merupakan proses evolusi normal mikroorganisme. ${ }^{2}$ Pengobatan dengan antibiotik betalaktam merupakan pengobatan paling umum untuk infeksi bakteri. ${ }^{3}$ Antibiotik betalaktam bersifat bakterisidal dengan menghambat sintesis dinding sel bakteri dan menyebabkan lisis sel bakteri. ${ }^{4}$ Paparan jangka panjang bakteri terhadap antibiotik betalaktam dalam jumlah besar dapat menginduksi produksi dan mutasi beta laktamase. ${ }^{5}$ Penggunaan antibiotik yang tidak tepat (pilihan, dosis, ketidakpatuhan pada pengobatan) pada pasien serta penggunaan antibiotik pada hewan juga berperan dalam perkembangan resistensi antibiotik. ${ }^{6,7}$

Extended spectrum beta laktamase adalah beta laktamase yang dapat menghidrolisis penisilin, sefalosporin dan aztreonam, tidak menghidrolisis cephamisin atau karbapenem dan diinhibisi oleh beta laktam inhibitor ${ }^{8,9}$ Prevalensi Escherichia coli dan Klebsiella pneumoniae penghasil ESBL meningkat dalam beberapa tahun ini. ${ }^{10}$

Infeksi bakteri penghasil ESBL memiliki pilihan terapi yang terbatas. ${ }^{9}$ Karbapenem digunakan sebagai terapi pilihan untuk infeksi invasif yang disebabkan oleh Enterobactericeae penghasil ESBL (ESBL-E) sehingga menyebabkan peningkatan penggunaan karbapenem sebagai terapi empiris dan terapi saat isolat ESBL-E ditemukan pada sampel pasien. Hal ini berkontribusi terhadap penyebaran resistensi karbapenem. ${ }^{8}$

Resistensi antibiotik membuat pemilihan antibiotik empiris lebih sulit. Pemilihan antibiotik empiris untuk bakteri ESBL-E seharusnya dilakukan berdasarkan antibiogram yang bervariasi disetiap rumah sakit. ${ }^{11}$ Penelitian ini bertujuan untuk mengetahui prevalensi dan pola sensitivitas antibiotik dari Klebsiella pneumoniae dan Escherichia coli penghasil ESBL di RSUP Dr. M. Djamil Padang.

\section{METODE}

Penelitian ini adalah studi deskriptif potong lintang yang dilakukan di Laboratorium Mikrobiologi RSUP Dr M Djamil Padang pada bulan Juni 2018 hingga Juni 2019. Populasi penelitian adalah semua sampel pasien dengan hasil kultur bakteri Gram negatif dari pemeriksaan dengan alat VITEK 2 dari berbagai spesimen klinis pasien (darah, sputum, pus, swab, urin, feses, cairan tubuh) RSUP Dr.M Djamil Padang pada bulan Juni 2018 hingga Mei 2019. Spesimen penelitian adalah bagian dari populasi yang memenuhi kriteria inklusi yaitu spesimen pasien dengan data hasil kultur bakteri Klebsiella pneumoniae dan Escherichia coli dengan hasil pemeriksaan ESBL positif.

Identifikasi Klebsiella pneumoniae dan Escherichia coli dilakukan dengan melihat morfologi koloni dan pewarnaan Gram. Pemeriksaan identifikasi dan uji sensitivitas dilakukan bersamaan dengan alat mikrobiologi otomatis VITEK 2 dengan teknologi kolorimetri dan turbidimetri. Prinsip pemeriksaan ESBL adalah inhibisi pertumbuhan bakteri dengan adanya asam klavulanat. Data meliputi asal ruangan, jenis spesimen, hasil uji sensitivitas terhadap beberapa antibiotik formularium nasional seperti ampisilin, ampisilin sulbaktam, seftazidim, seftriakson, sefepim, meropenem, amikasin, gentamisin,siprofloksasin dan trimetoprim/ sulfametoksazol dikumpulkan. Data yang didapat, diolah dan disajikan dalam bentuk tabel.

\section{HASIL}

Spesimen penelitian dengan hasil kultur bakteri Gram negatif selama periode Juni 2018 hingga Mei 2019 didapatkan sebanyak 3201 spesimen. Spesimen dengan hasil kultur bakteri Klebsiella pneumoniae dan Escherichia coli sebanyak 1136 spesimen dan yang memenuhi kriteria inklusi sebanyak 828 spesimen.

Spesimen pasien terbanyak merupakan sputum $418(50,7 \%)$, diikuti urin dan pus masing masing sebanyak 193 (23,6\%) dan 104 (12,3\%), sedangkan sisanya merupakan sampel feses, swab, darah dan cairan tubuh. Spesimen terbanyak dikirimkan dari bagian interne sebanyak 439 (53\%), diikuti dengan 
bagian Paru dan anak sebanyak masing-masing 76 (9,2\%) dan 64 (7,7\%). Prevalensi bakteri Klebsiella pneumoniae dan Escherichia coli penghasil ESBL dapat dilihat pada Tabel 1.

Tabel 1. Prevalensi bakteri Klebsiella pneumoniae dan Escherichia coli penghasil ESBL

\begin{tabular}{|c|c|c|c|c|}
\hline \multirow[t]{2}{*}{ Bakteri } & \multicolumn{2}{|c|}{$\begin{array}{l}\text { Klebsiella } \\
\text { pneumonia }\end{array}$} & \multicolumn{2}{|c|}{ Escherichia coli } \\
\hline & Jumlah & $\begin{array}{l}\text { Preva- } \\
\text { lensi }\end{array}$ & Jumlah & $\begin{array}{l}\text { Preva-- } \\
\text { lensi }\end{array}$ \\
\hline $\begin{array}{l}\text { ESBL } \\
\text { positif }\end{array}$ & 476 & $70,9 \%$ & 352 & $75,7 \%$ \\
\hline $\begin{array}{l}\text { ESBL } \\
\text { negatif }\end{array}$ & 195 & $29,1 \%$ & 113 & $24,3 \%$ \\
\hline Total & 671 & $100,0 \%$ & 465 & $100,0 \%$ \\
\hline
\end{tabular}

Prevalensi Klebsiella pneumoniae penghasil ESBL sebanyak $70,9 \%$ sedangkan prevalensi Escherichia coli penghasil ESBL adalah $75,7 \%$. Pola sensitivitas antibiotik dari Klebsiella pneumoniae dan Escherichia coli penghasil ESBL dapat dilihat pada Tabel 2 dan 3.

Tabel 2. Pola sensitivitas antibiotik dari Klebsiella pneumoniae penghasil ESBL terhadap beberapa antibiotik formularium nasiona

\begin{tabular}{lrrr}
\hline & \multicolumn{3}{c}{ Klebsiella pneumoniae } \\
\hline Antibiotika & \multicolumn{1}{c}{ S } & \multicolumn{1}{c}{ I } & \multicolumn{1}{c}{ R } \\
\hline Amikasin & $98,8 \%$ & $0,6 \%$ & $0,6 \%$ \\
Meropenem & $96,4 \%$ & $0,4 \%$ & $3,2 \%$ \\
Sefepim & $53,5 \%$ & $0,2 \%$ & $46,3 \%$ \\
Gentamisin & $46,2 \%$ & $0,6 \%$ & $53,2 \%$ \\
Siprofloksasin & $31,5 \%$ & $7,3 \%$ & $61,2 \%$ \\
Trimetoprim/ & $23,5 \%$ & $0 \%$ & $76,5 \%$ \\
sulfametoksazol & & & \\
Seftazidim & $15,3 \%$ & $13,0 \%$ & $71,7 \%$ \\
Ampisilin /sulbaktam & $6,3 \%$ & $13,2 \%$ & $80,5 \%$ \\
Seftriakson & $1,2 \%$ & $0 \%$ & $98,8 \%$ \\
Ampisilin & $0 \%$ & $0 \%$ & $100 \%$
\end{tabular}

Sensitivitas Klebsiella pneumoniae penghasil ESBL terhadap antibiotik meropenem, amikasin, sefepim, gentamisin masing-masing didapatkan sebesar 98,9, 99,4\%, 44,8\% dan 53,4\%. Sensitivitas Escherichia coli penghasil ESBL terhadap antibiotik meropenem, amikasin, sefepim, gentamisin didapatkan masing-masing sebesar 96,4\%, 98,9\%, 53,5\% dan 46,2\%. Sensitivitas Escherichia coli dan
Klebsiella pneumoniae penghasil ESBL terhadap antibiotik lainnya dibawah $50 \%$.

Tabel 3. Pola sensitivitas antibiotik dari Escherichia coli penghasil ESBL terhadap beberapa antibiotik formularium nasional

\begin{tabular}{lrrr}
\hline & \multicolumn{3}{c}{ Escherichia coli } \\
\hline Antibiotika & \multicolumn{1}{c}{ S } & \multicolumn{1}{c}{ I } & \multicolumn{1}{c}{ R } \\
\hline Amikasin & $99,4 \%$ & $0 \%$ & $0,6 \%$ \\
Meropenem & $98,9 \%$ & $0 \%$ & $1,1 \%$ \\
Sefepim & $44,8 \%$ & $0 \%$ & $55,2 \%$ \\
Gentamisin & $53,4 \%$ & $0 \%$ & $46,6 \%$ \\
Siprofloksasin & $15,9 \%$ & $2,0 \%$ & $82,1 \%$ \\
Trimetoprim/ & $17,0 \%$ & $0 \%$ & $83 \%$ \\
sulfametoksazol & & & \\
Seftazidim & $27,8 \%$ & $1,4 \%$ & $70,8 \%$ \\
Ampisilin /sulbaktam & $21,8 \%$ & $16,8 \%$ & $61,4 \%$ \\
Seftriakson & $0,6 \%$ & $0 \%$ & $99,4 \%$ \\
Ampisilin & $0 \%$ & $0 \%$ & $100 \%$ \\
\hline
\end{tabular}

\section{PEMBAHASAN}

Prevalensi Klebsiella pneumoniae dan Escherichia coli penghasil ESBL di RSUP Dr. M Djamil Padang yang didapatkan dari penelitian ini masingmasing sebesar 70,9\% dan 75,7\%. Hasil ini lebih tinggi dari penelitian lain seperti Anggraini et al (2018), mendapatkan prevalensi Klebsiella pneumoniae dan Eschericia coli penghasil ESBL di RSUD Arifin Achmad Pekanbaru pada tahun 2015 masing-masing sebesar $66,2 \%$ dan $65,2 \% .^{5}$

Tingginya prevalensi infeksi Klebsiella pneumoniae dan Eschericia coli penghasil ESBL di RSUP Dr. M Djamil Padang dapat dipengaruhi oleh kondisi pasien yang dirawat di rumah sakit ini. Pasien berat yang telah lama dirawat di RS dan pasien yang menggunakan alat invasif (kateter urin, nasogastric tubes, endotracheal tube, arterial line dan central venous line) merupakan pasien berisiko tinggi untuk kolonisasi dan infeksi bakteri penghasil ESBL. Risiko kolonisasi atau infeksi ESBL lainnya termasuk riwayat operasi baru-baru ini, diabetes, hemodialisa, ulkus dekubitus dan status nutrisi yang buruk. ${ }^{9}$ Riwayat penggunaan antibiotik (jumlah total) juga merupakan faktor risiko infeksi Escherischia coli dan Klebsiella pneumoniae penghasil ESBL. ${ }^{10}$

Tumbarello et al (2011) menemukan bahwa ada 6 faktor yang berhubungan dengan isolasi E.coli, $K$. pneumoniae dan Proteus mirabilis dalam 48 jam 
perawatan termasuk terapi dengan beta laktam dan/atau florokuinolon, riwayat perawatan di RS sebelumnya, pasien yang dipindahkan dari fasilitas kesehatan lain, riwayat penggunaan kateter, skor komorbiditas Charlson $>4$ dan usia 70 tahun. $^{12}$ Johnson et al (2013) mengevaluasi model italian oleh Tumbarello et al, menambahkan faktor imunosupresi dan mengeluarkan faktor Komorbiditas Charlson dan usia. $^{13}$

Sensitivitas Klebsiella pneumoniae penghasil ESBL terhadap antibiotik meropenem dan amikasin di RSUP Dr M Djamil Padang didapatkan sebesar 98,9 dan 99,4\%. Sensitivitas Escherichia coli penghasil ESBL terhadap antibiotik meropenem dan amikasin juga didapatkan masing-masing sebesar 96,4\% dan 98,9\%. Hal ini sesuai dengan penelitian Anggraini et al, di RSUD Arifin Achmad yang juga mendapatkan sensitivitas Klebsiella pneumoniae penghasil ESBL terhadap meropenem dan amikasin sebesar 94,0\%, 96,7\% dan sensitivitas Escherichia coli penghasil ESBL terhadap meropenem dan amikasin sebesar 98,0\% dan 100,0\%. ${ }^{5}$ Penelitian pada sebuah Rumah Sakit di Surabaya juga menunjukkan Klebsiella pneumoniae penghasil ESBL memiliki sensitivitas sebesar $96,5 \%$ dan $86,6 \%$ terhadap antibiotik meropenem dan amikasin serta Escherichia coli penghasil ESBL memiliki sensitivitas terhadap antibiotik meropenem dan amikasin sebesar 100\% dan $90,6 \%{ }^{14}$

Golongan karbapenem merupakan obat pilihan untuk infeksi berat bakteri penghasil ESBL. ${ }^{5,15}$ Terapi meropenem untuk infeksi ESBL pada penelitian observasional berhubungan dengan kegagalan terapi yang rendah dan keluaran yang baik. ${ }^{15}$ Resistensi terhadap meropenem didapatkan pada $1,1 \%$ Klebsiella pneumoniae dan 3,2\% Escherischia coli pada penelitian ini. Resistensi karbapenem dapat disebabkan oleh induksi ekspresi berlebihan dari sefalosporinase kromosomal seperti AmpC dengan kombinasi hilangnya porin atau akuisisi gen karbapenem melalui elemen genetik yang dapat berpindah. $^{16}$ Beberapa bakteri penghasil karbapenemase juga menghasilkan ESBL. Terapi yang dapat diberikan pada Enterobactericeae resisten karbapenem termasuk antibiotik polimiksin, tigesiklin, fosfomisin dan terkadang aminoglikosida. Beberapa isolat juga sensitif dengan minosiklin, doksisiklin, kloramfenikol, trimetoprim sulfametoksazol dan temocilin. $^{17}$

Terapi untuk Enterobactericeae resisten karbapenem harus berdasarkan pemeriksaan uji sensitivitas, sumber, beratnya infeksi dan data dari penelitian klinis. Penggunaan terapi kombinasi antibiotik dapat berguna untuk pasien dengan risiko tinggi tergantung situasi, sumber infeksi, adanya syok sepsis sementara monoterapi mungkin cukup untuk pasien dengan risiko lebih rendah. ${ }^{17}$

Sensitivitas Klebsiella pneumoniae dan Escherischia coli penghasil ESBL terhadap amikasin di RSUP Dr. M Djamil Padang adalah 99,4\% dan 98,9\% sementara sensitivitas Klebsiella pneumonia dan Escherichia coli penghasil ESBL terhadap antibiotik gentamisin adalah 46,2\% dan 53,4\%. Golongan aminoglikosida masih dapat menjadi pilihan terapi empiris sebagai monoterapi atau kombinasi dengan betalaktam pada daerah dimana prevalensi ESBL tinggi terutama pada sepsis dan infeksi saluran kemih dimana penggunaan golongan karbapenem dibatasi dan diganti dengan obat yang lebih sesuai setelah hasil uji sensitivitas diketahui karena efek toksisitasnya. ${ }^{17}$

Sensitivitas Klebsiella pneumonia dan Escherichia coli penghasil ESBL terhadap antibiotik sefepim di RSUP Dr. M Djamil Padang adalah 53,5\% dan 44,8\%. Thomson et al, menemukan bahwa sefepim adalah golongan sefalosporin yang kurang dipengaruhi oleh efek inokulum daripada sefotaksim dan seftriakson. Efek inokulum ini menunjukkan bahwa sefepim lebih tahan terhadap inaktivasi ESBL tetapi penggunaan untuk terapi pada infeksi berat harus dimonitor ketat untuk menilai apakah terjadi kegagalan terapi. ${ }^{18}$ Sefepim dosis tinggi dapat diberikan pada isolat bakteri Gram negatif penghasil ESBL dengan MIC (minimal inhibitory concentration) $\leq$ $2 \mathrm{mg} / \mathrm{L}^{19}$

Sensitivitas Klebsiella pneumoniae penghasil ESBL terhadap antibiotik siprofloksasin dan trimetoprim/sulfametoksazol hanya $31,5 \%$ dan $23,5 \%$ sedangkan sensitivitas Escherischia coli penghasil ESBL terhadap antibiotik siprofloksasin dan trimetoprim/sulfametoksazol $15,9 \%$ dan $17 \%$. Plasmid yang membawa gen ESBL juga mengkode resistensi 
terhadap obat golongan lain (quinolon, aminoglikosida dan trimetoprim/sulfametoksazol) sehingga banyak agen non beta laktam tidak dapat digunakan untuk infeksi bakteri penghasil ESBL. ${ }^{15}$

Sensitivitas Klebsiella pneumoniae dan Escherischia coli penghasil ESBL kombinasi ampicillin/sulbaktam hanya $6,3 \%$ dan $21,8 \%$. Kegagalan kombinasi betalaktam/betalaktamase inhibitor dapat disebabkan oleh plasmid yang dapat membawa beta laktamase lainnya yang tidak dapat diinhibisi oleh clavulanat atau tazobactam (contohnya plasmid-derived $A m p C$ ), ekspresi berlebihan beta laktamase yang melebihi aktivitas beta laktamase inhibitor, terjadinya penurunan permeabilitas membran atau mekanisme efflux. Terapi kombinasi betalaktam/betalaktam inhibitor merupakan pilihan terapi selain karbapenem terutama pada infeksi ringan. Terapi ini dapat diberikan pada infeksi saluran kemih (termasuk bakteremia) atau infeksi lain dengan isolat yang sensitif pada uji sensitivitas pada MIC rendah dan saat sumber infeksi telah terkontrol. ${ }^{20}$

Sensitivitas Klebsiella pneumoniae dan Escherischia coli penghasil ESBL terhadap antibiotik seftazidim masing masing $15,3 \%$ dan $27,8 \%$ dan terhadap seftriakson $1,2 \%$ dan $0,6 \%$. DelgadoValverde et al hanya merekomendasikan penggunaan sefalosporin dapat dilanjutkan pada pasien dengan sepsis karena infeksi saluran kemih oleh bakteri penghasil ESBL bila setelah diberikan sebagai terapi empiris terdapat perbaikan pada pasien dan hasil uji sensitivitas menunjukkan MIC yang rendah (sesuai ambang batas MIC terbaru). ${ }^{15}$

Penelitian ini hanya meneliti prevalensi dan pola sensitivitas antibiotik dari Klebsiella pneumoniae dan Escheriscia coli terhadap beberapa antibiotik formularium Nasional. Pola sensitivitas antibiotik Klebsiella pneumoniae dan Escherichia coli juga tidak dipisahkan berdasarkan ruangan dan jenis sampel.

\section{SIMPULAN}

Sensitivitas Klebsiella pneumoniae terhadap antibiotik meropenem, amikasin, sefepim, gentamisin didapatkan sebesar 98,9, 99,4\%, 44,8\% dan 53,4\%. Sensitivitas Escherichia coli terhadap antibiotik meropenem, amikasin, sefepim, gentamisin didapatkan masing-masing sebesar 96,4\%, 98,9\%, $53,5 \%$ dan $46,2 \%$.

\section{SARAN}

Pemilihan terapi antibiotik terhadap infeksi Klebsiella pneumoniae dan Escherichia coli penghasil ESBL disesuaikan dengan hasil uji sensitivitas antibiotik.

\section{DAFTAR PUSTAKA}

1. World Health Orgenization (WHO). Global antimicrobial resistance surveillance syatem (GLASS) Report: Early Implementation 2016-2017. Geneva: WHO; 2017.

2. World Health Organization (WHO). Antimicrobial resistance global report on surveillance 2014. Switzerland: WHO; 2014.

3. Saikh S, Fatima J, Shakil S, Rizvi SMH, Kamal MA. Antibiotic resistance and extended spectrum beta-laktamase: types, epidemiology and treatment. Saudi Journal of Biological Sciences. Elsevier.2015;(22): 90-101.

4. Rahman SU, Ali T, Ali I, Khan NA, Han B, Gao J. The growing genetic and functional diversity of extended-spectrum beta lactamases. BioMed Res Int. 2018;(2018):1-14

5. Anggraini D, Hasanah SU, Savira M, Andrini DF, Irawan D, Prima RR. Prevalensi dan pola sensitivitas enterobacteriaceae penghasil ESBL di RSUD Arifin Achmad Pekanbaru. Jurnal Kedokteran Brawijaya. 2018;30(1):47-52.

6. Ayukekbong JA, Ntemgwa M, Atabe AN. The treat of antimicrobial resistence in developing countries : causes and control strategies. Antimicrobial resistence and Infection Control. 2017;6(47):1-8.

7. Prestinaci F, Pezzotti P, Pantosti A. Antimicrobial resistance: a global multifaceted phenomenon. Pathogen and Global Health. 2015;109(7):309-18.

8. Retamar P, Bano-J R, Paul M, Hussein K, AMS in a era of multidrug- resistant bacteria. Dalam: Pulcini C, Ergonul O, Can F, Beovic B, editor (penyunting). Antimicrobial Stewardship: Development Emerging and Existing Infectious Diseases. Edisi ke-2. London: Elsevier. 2017.hlm. 219-31. 
9. Rawat D, Nair D. Extended-spectrum $\beta$-laktamase In Gram Negative Bacteria. Journal of Global Infectious Disease. 2010;2(3):263-74.

10. Lautenbach E, Patel JB, Bilker WB, Edelstein PH, Fishman NO. Extended-spectrum $\beta$-Lactamaseproducing escherichia coli and klebsiella pneumoniae: risk factor for infection and impact of resistance on outcomes. Clinical Infectious Disease. 2001;(32):1162-7.

11. Amelia A, Nugroho A, Harijanto PN. Diagnosis and management of Infections Caused by Enterobactericeae Producing Extended-Spectrum $\beta$-Laktamase. Acta Med Indones-Indones J Intern Med. 2016;48(2):157-66.

12. Tumbarello M, Trecaarichi EM, Basetti M, De Rosa FG, Spanu T, Di Meco E, et al. Identifying patients harboring extended-spectrum- $\beta$-lactamaseproducing enterobactericeae on hospital admission: derivation and validation of a scoring system. Antimicrob Agents Chemother. 2011; 55(7): 3485-90.

13. Johnson SW, Anderson DJ, May DB, Drew RH. Utility of clinical risk factor scoring model in predicting infection with extended-spectrum $\beta$ laktamase-producing Enterobacteriaceae on hospital admission. Infect control Hosp Epidemiologi. 2013;34(4):385-92.

14. Kuntaman K, Santoso S, Wahjono H, Mertaniasih $\mathrm{NM}$, Lestari ES, Farida $\mathrm{H}$, et al. The sensitivity pattern of extended spectrum beta lactamaseproducing bacteria against six antibiotics that routinely used in clinical setting. J Indon Med Assoc. 2011;61(12):482-6.

15. Delgado-Valverde M, Sojo-Dorado J, Pascual A.Clinical Management of Infection Caused by Multidrug-resistant Enterobactectericeae. Ther Adv Infec Dis. 2013:1(2); 49-69.

16. Wilson $H$, Torok ME. Extended-spectrum $\beta$ laktamase-producing and carbapenemaseproducing Enterobacteriaceae. Microbial Genomics. 2018;(4):1-14.

17. Rodriguez-Bano J, Gutierrez-Gutierrez B, Machuca I, Pascual A. Treatment of infections caused by extended spectrum beta Lactamase, AmpC and Carbapenemase producing Enterobactericeae. Clinical Microbiology Review. 2018;31(2):1-42.

18. Thomson K S, Moland E S. Cefepime, piperacillintazobactam, and the inoculum effect in tests with extended-spectrum $\quad \beta$-Lactamase-producing Enterobactericeae. Antimicrob Agents and Chemother.2001;45(12):3548-54.

19. Daikos G L, Souli M, Antoniadou A. Management strategies for drug resistant infections. Dalam Cohen J, Powderly WG, Opal SM, editor (penyunting) Infectious Disease Edisi ke- 4. China: Elsevier; 2017.hlm.1289-92.

20. Harris PNA, Tambyah PA, Paterson DL. $\beta$-lactam and $\beta$-lactamase inhibitor combinations in the treatment of extended spectrum $\beta$-lactamase producing Enterobactericeae: Time for reappraisal in the new era of few antibiotic options? Lancet Infect Dis. 2015;(14):1-10. 